\title{
IMPLEMENTASI METODE BELAJAR ROLE PLAYING UNTUK MENINGKATKAN HASIL BELAJAR SISWA KELAS VIII C MATA PELAJARAN IPS MTsN BATU
}

\author{
Putri Aulia Enan Dina \\ Program Studi Pendidikan Agama Islam \\ Universitas Islam Negeri Maulana Malik Ibrahim Malang \\ putrienan02@yahoo.com \\ Rasmuin \\ Dosen Program Studi Pendidikan Agama Islam \\ Universitas Islam Negeri Maulana Malik Ibrahim Malang \\ muin@uin-malang.ac.id
}

\begin{abstract}
Abstrak
Penelitian ini bertujuan untuk mengetahui pengaruh metode belajar role playing dalam kegiatan pembelajaran IPS dalam meningkatkan hasil belajar peserta didik kelas VIII-C MTs1N Batu. Metode penelitian ini yaitu deskriptif kualitatif dengan pendekatan penelitian tindakan kelas. Pengambilan data menggunakan teknik wawa1ncara, tes, dan obser1vasi. Hasil penelitian menunjukkan bahwa terdapat perubahan positif pada hasil belajar siswa. Peningkatan hasil bellajar bisa dilihat berdasarkan pencapaian nilai hasil eval1uasi disetiap siklus. Dilihat dari hasil evaluasi menunjukkan bahwa skor rerata pada pra siklus hingga kegiatan siklus II menggambarkan peningkatan skor yang signifikan. Rerata nilai pada pra siklus yang diambil dari data Ulangan Harian sebesar 61,75, hasil evaluasi siklus I rerata nilai sebesar 76,2 sedangkan aktivitas siklus II memperoleh nilai rata-rata meningkat diangka 89,4.
\end{abstract}

\section{Kata kunci : Hasil Belajar, Metode, Role Playing}

\section{Abstract}

This study aims to determine the effect of role playing learning methods in social science learning activities in improving the learning outcomes of students grade VIII-C of MTsN Batu. This research method is descriptive qualitative with a clasroom action research approach. Data collection using interview techniques, tests, and observations. The results showed that there were positive changes in student learning outcomes significantly. the average student learning outcomes in the pre-cycle of 61.75, 
Putri Aulia Enan Dina, Rasmuin : Implementasi Metode Belajar Role Playing untuk

Meningkatkan Hasil Belajar Siswa Kelas VIII C Mata Pelajaran IPS Mtsn Batu

increased in the first cycle to 76.2 and last 89.4 after the second cycle

\section{Keywords: Learning Outcomes, Methods, Role Playing}

\section{A. PENDAhUluan}

Hakikat belajar adalah perubahan diri seseorang setelah kegiatan pembelajaran selesai. Sedangkan proses pengaturan dan pengorganisasian lingkungan di sekitar peserta didik merupakan hakikat dari mengajar. ${ }^{49}$ Untuk menunjang keberhasilan pembelajaran, guru dan peserta didik harus bersinergi mewujudkan kegiatan belajar mengajar yang kondusif. Komponen penentu keberhasilan pendidikan juga dapat dilihat dari beberapa aspek diantaranya materi, media, dan metode pembelajaran.

Stigma kegiatan belajar mengajar di dunia pendidikan lebih berporos pada pendidik (teacher centered) bukan pada siswa (student centered). Paradigma lama dalam dunia pendidikan beranggapan bahwa guru memiliki kendali penuh dalam menjalankan kewajiannya untuk mengajar dan membagi informasi-informasi pengetahuan, sehingga aktifitas siswa terbatas dan pasif. Permasalahan yang sering dialami seorang guru adalah lemahnya kemampuan menciptakan minat belajar siswa dalam kegiatan belajar mengajar. Banyak dijumpai seorang guru masih menerapkan1 metode1 ceramah secara menyeluruh pada kegiatan pembelajaran dan kegiatan siswa hanya sekedar mendengar, mencatat, dan menghafal. Imbas dari permasalahan tersebut yaitu guru sulit menarik perhatian dan keaktifan belajar siswa. Permasalahan ini dapat mempengaruhi

49 Syaiful bahrir Djamarah1, Psikologi1 Belajar, (Jakarta: PT. Rineka Cipta, 2005), hal 45 
Putri Aulia Enan Dina, Rasmuin : Implementasi Metode Belajar Role Playing untuk Meningkatkan Hasil Belajar Siswa Kelas VIII C Mata Pelajaran IPS Mtsn Batu

prestasi belajar siswa. Metode pembelajaran yang kurang baik dapat menyebabkan kurang berkualitasnya belajar siswa. ${ }^{50} 1$

Penciptaan kegiatan pembelajaran yang menyenangkan perlu dimunculkan agar pembelajaran tidak monoton dan membosankan. Hal ini dapat mendobrak proses pembelajaran Passif Learning menjadi Aktive learning. Kegiatan pembelajaran yang menyenangkan dapat menambah keberhasilan proses pembelajaran. Untuk memunculkan kegiatan belajar menyenangkan guru dapat menerapkan metode1-meto1de pembelajaran. Manfaat metode pembelajaran menjadi salah satu alat mencapai tujuan pembelajaran. ${ }^{51}$ Semangat dan ketertarikan siswa pada pembelajaran dapat bertambah sehingga pemahaman materi lebih mudah dicapai.

Salah satu gaya pembelajaran yang menyenangkan dan mengutamakan proses 1 pada pembelajaran peserta didik adalah metode Role Playing. Metode pembelajaran ini juga1 umum disebut dengan "bermain peran" atau sosio drama. Metode ini memotivasi peserta didik untuk memerankan karakter yang disajikan dengan inti informasi dalam pembelajaran. Dasar kegiatan sosio drama yaitu mendramatisasikan aktivitas atau tingkah laku yang dihubungkan dengan permasalahan sosial. 52

Keaktifan siswa dalam metode role playing atau sosio drama muncul saat memperagakan drama atau menyimak drama yang ditampilkan. Manfaat dari metode role playing ini siswa lebih mudah menguasai inti pembelajaran secara

50 Slameto1, Belajar dan Faktor1 yan1g 1 me1 mpengaruhinya, (Jakarta: Rineka Cipta, 2010), Hal 65

51 Hamzah B. Uno, Model Pembelajaran. (Jakarta: Bumi Aksara, 2008), hal 2

52 Syaiful Bahri Djamarah dan Aswan Zain. (Strategi Belajar Mengajar. Jakarta: Rineka Cipta, 2002), Hal 101 
Putri Aulia Enan Dina, Rasmuin : Implementasi Metode Belajar Role Playing untuk Meningkatkan Hasil Belajar Siswa Kelas VIII C Mata Pelajaran IPS Mtsn Batu

menyeluruh karena siswa ikut serta dalam memerankan seseorang. ${ }^{53}$

Pada prosesnya siswa akan mampu menghargai dan menghayati perasaan orang lain, mampu berbagi rasa bertanggung jawab, mampu memahami bagaimana memanajemen keputusan tim, dan mampu mencari solusi untuk memecahkan masalah. Penggunaan metode pembelajaran role playing di pelajaran IPS pada materi "mobilitas sosial", siswa diajarkan untuk mengerti, memahami, dan mengenal mobilitas sosial di lingkungan sekitar. Dengan menggunakan metode role playing diharapkan mampu untuk menumbuhkan suasana belajar yang lebih disukai siswa, tidak monoton dikelas, serta siswa bisa mengekspresikan perasaannya melaui kegiatan pembelajaran.

Penelitian ini diadakan di MTs Negeri Kota Batu kelas VIII-C. Alasan peneliti memilih kelas VIII-C karena siswasiswinya memiliki karakteristik yang unik. Di dalam kelas, siswa cenderung lebih suka berbicara dengan temannya, melakukan aktivitas diluar kegiatan pembelajaran, dan senang berjalanjalan di dalam kelas. Penempatan jam mata pelajaran IPS yang ditempatkan di jam terakhir sekolah sedikit banyak mempengaruhi semangat belajar siswa karena pada jam-jam tersebut sudah mengalami kelelahan dalam beraktivitas seharian. Pemilihan metode ini juga didasari atas keberanian para siswa untuk berbicara di depan kelas. Kemampuan tersebut juga diiringi dengan mental siswa yang tidak malu menampilkan dirinya didepan teman-temannya.

53 Kiromim 1 Baroroh. Upaya Meningkatkan 1Nilai-Nilai Karakter Peserta Didik Melalui Penerapan 1Metode Role Playing. (Jurnal Ekonomi \& Pendidikan. Volume 8 Nomor 2. November 2011). Hal 162 
Putri Aulia Enan Dina, Rasmuin : Implementasi Metode Belajar Role Playing untuk Meningkatkan Hasil Belajar Siswa Kelas VIII C Mata Pelajaran IPS Mtsn Batu

Dari pengamatan peneliti sebelum melaksanakan tindakan, aktivitas bela1jar mengajar1 di kelas VIII-C MTs Negeri Batu masih perlu perbaikan. Guru sudah berusaha menciptakan minat belajar siswa dengan menggunakan media audiovisual berupa video pembelajaran. Aktifitas siswa sudah ditonjolkan di penilaian portofolio seperti pembuatan peta konsep, merangkum, dan pembuatan produk. Pengerjaan portofolio tersebut dilaksanakan setelah guru menjelaskan isi materi. Guru membebaskan siswa memilih lokasi pengerjaan portofolio (didalam kelas maupun diluar kelas) di area sekolah. Namun tindakan yang dilakukan guru masih belum mampu meningkatkan minat siswa secara menyeluruh dalam belajar. Siswa sering tidak terkontrol, bosan, dan tidak teratur saat kegiatan belajar mengajar. hal ini dikarenakan pengawasan guru kurang mencakup seluruh kegiatan siswa terutama saat pengerjaan portofolio yang dikerjakan ditempat terpisah. Selain itu, siswa menganggap bahwa belajar IPS tidak terlalu krusial dalam mempelajarinnya karena mata pelajaran IPS tidak termuat dalam ujian nasional. Hal ini memicu rendahnya minat dan motivasi siswa dalam belajar IPS. Menumbuhkan minat siswa dalam belajar perlu ditingkatkan dengan tujuan hasil belajar siswa juga ikut meningkat.

Dari paparan diatas dapat diidentifikasikan bahwa kurangnya minat belajar IPS di MTs negeri Kota Batu kelas VIIIC dikarenakan (1) jam pelajaran IPS berada di siang hari sehingga siswa kelelahan dalam menerima pelajaran (2) siswa merasa bosan dalam kegiatan belajar mengajar (3) siswa menganggap belajar IPS kurang penting karena tidak masuk dalam ujian nasional. 
Putri Aulia Enan Dina, Rasmuin : Implementasi Metode Belajar Role Playing untuk Meningkatkan Hasil Belajar Siswa Kelas VIII C Mata Pelajaran IPS Mtsn Batu

Dari studi literatur yang peneliti lakukan terdapat beberapa penelitian sejenis diantaranya penelitian yang dilakukan oleh Riry Madiyan, metode belajar Role Playing sanggup meningkatkan keaktifan dan hasil belajar siswa mata pelajaran akuntansi. Rata-rata hasil belajar di setiap siklus mengalami kenaikan. Perolehan rata-rata hasil belajar pada siklus I sebesar 58,16\% dan meningkat di siklus II menjadi $74,94 \%$. Tingkat ketuntasan belajar siswa di siklus I sebesar $83 \%$ sedangkan pada siklus II telah mencapai $100 \%$. Keaktifan siswa dalam proses pebelajaran berdampah terhadap hasil belajar siswa. Semakin aktif seorang siswa dalam pembelajaran maka semakin paham siswa tersebut dalam menangkap materi. Hal ini akan berdampak positif pada ketuntasan hasil belajar siswa. 54

Penelitian kedua yang dilakukan oleh Nuha Murtadlo memaparkan hal yang sama bahwa melaui metode Role Playing keaktifan siswa dalam pembelajaran mampu ditingkatkan. Keaktifan siswa pada siklus I pertemuan pertama berada pada tingkat rendah, pada pertemuan kedua siklus I dan pertemuan pertama di siklus II keaktifan siswa naik di kategori cukup, sedangkan pada siklus II pertemuan kedua keaktifan siswa naik pada level tinggi. Hal ini juga sejalan dengan kenaikan hasil belajar yang diperoleh ditinjau dari nilai evaluasi disetiap siklus. 55

54 Riry Mardiyan, "Peningkata Keaktifan dan Hasil Belajar Siswa dalam Pembelajaran Akuntansi Materi Jurnal Penyesuaian pada Siswa Kelas XI IPS 3 SMA Negeri 3 Bukit Tinggi dengan Metode Bermain Peran(Role Playing)". Pakar Pendidikan, VOL. 10 NO. 2 JULI 2012 (151-162)

55 Muhamad Nukha Murtadlo, "Penerapan Metode Role Playing pada Standar Kompetensi Memahami Kegiatan pelaku Ekonomi di Masyarakat Mata Pelajaran IPS Ekonomi Sebagai Upaya Peningkatan Hasil Belajar SMP 4 Kudus". Economic Educatin Analysis Journal 1 (1) (2012) 
Putri Aulia Enan Dina, Rasmuin : Implementasi Metode Belajar Role Playing untuk Meningkatkan Hasil Belajar Siswa Kelas VIII C Mata Pelajaran IPS Mtsn Batu

Ketiga penelitian Tien Kartini mengemukakan bahwa implementasi metode belajar role playing secara efektif sanggup meningkatkan minat siswa dalam pembelajaran. Keaktifan siswa meningkat dan serta kemampuan menyampaikan pendapat menjadi lebih baik. Metode role playing mampu mengembangkan kreativitas guru dalam meningkatkna motivasi dan minat belajar siswa. 56

Maka dari itu, peneliti ingin membantu menambah pengalaman belajar1 IPS di MTs Negeri1 Batu de1ngan mengadakan Pen1elitian1 Tindakan Kellas (PTK) pada siswa kelas VIII-C pada materi "Mobilitas Sosial". Penelitian ini hendaknnya bisa meningkatkan hasil belajar siswa dan pengalaman belajar siswa yang menyenangkan.

\section{B. METODE PENELITIAN}

Metode penelitian ini yaitu deskriptif kualitatif melalui pendekatan Penelitian Tindakan Kelas (PTK). Pada penelitian kali ini peneliti memilih subjek penelitian yaitu siswa kelas VIIIC di MTs Negeri Batu dengan jumlah 20 siswa. Penelitian ini berfokus pada kegiatan pembelajaran IPS didalam kelas sebagai objek penelitian. Pengumpulan data diperoleh dari hasil tes, wawancara, dan observasi.

Penelitian Tindakan Kelas ini terdapat tiga tahap yaitu tahap pra siklus atau tindakan awal, siklus I, dan Siklus II. Tahapan penelitian disetiap siklus diantaranya: tahap persiapan, yaitu perancangan rencana pembelajaran yang sesuai dengan permasalahan yang didapati, tahap pelaksanaan tindakan, yaitu penerapan rencana pembelajaran, tahap

56 Tien Kartini, "Penggunaan Metode Role Playing untuk meningkatkan minat siswa dalam pembelajaran pengetahuan sosial di kelas V SDN Cileunyi I Kecamatan Cileunyi Bandung”. Pendidikan Dasar, Nomor: 8 Oktober 2007 
Putri Aulia Enan Dina, Rasmuin : Implementasi Metode Belajar Role Playing untuk

Meningkatkan Hasil Belajar Siswa Kelas VIII C Mata Pelajaran IPS Mtsn Batu

observasi atau penelitian, dan tahap refleksi, yaitu meninjau atau menganalisis kegiatan yang telah dilakukan.

\section{PEMBahasan}

Pendidikan Ilmu Pengetahuan Sosial (IPS) memiliki misi menyiapkan siswa menjadi warga negara yang baik dan mampu menanggapi dan menyelesaikan isu-isu sosial di kehidupan. Pembelajaran IPS difokuskan pada aspek pembekalan dan pendikan siswa. Pembelajaran tidak hanya mentransfer ilmu hafalan konsep saja melainkan ditekankan pada kemampuan mengelola pengetahuan siswa yang menjadi bekal kehidupan di lingkungan sosialnya. Selain itu tujuan oembelajran IPS yaitu mengiringi siswa untuk meraih pendidikan ke jenjang lebih tinggi lagi.57 Guru perlu meningkatkan strategi, model, dan metode pembelajaran agar upaya menyiapkan siswa menajdi warga negara yang baik dan mampu mengatasi isu-isu sosial dapat terealisasi.

Belajar yang menyenangkan menjadi idola bagi setiap siswa. Kegiatan belajar mengajar identik dengan ceramah, tekanan dan hal-hal lain yang membosankan. Bahan ajar yang semakin lama semakin berat bagi siswa ditambah dengan waktu pembelajaran yang panjang sangat berpengaruh pada minat dan kesiapan siswa. 58 Makna belajar yang menyenangkan bukan sekedar proes belajar mengajar yang berporos pada kegiatan hiburan dan bersenang-senang, melainkan penciptaan suasana belajar yang efektif dan mendukung komunikasi antara guru

57 Septian Aji Permana, Strategi Pembelajaran IPS Kontemporer, (Yogyakarta: media akademi, 2017) hal 3 hal 116

58 Moh. Yamin, "Teori dan Metode Pembelajaran", (Malang: Madani, 2014) 
Putri Aulia Enan Dina, Rasmuin : Implementasi Metode Belajar Role Playing untuk Meningkatkan Hasil Belajar Siswa Kelas VIII C Mata Pelajaran IPS Mtsn Batu

dan peserta didik. Hal ini bermaksud untuk mencapai tujuan pembelajaran.

Metode mengajar merupakan cara yang digunakan pendidik untuk menyalurkan ilmu kepada siswa. Pemilihan metode belajar harus sesuai dengan harapan dan tujuan pembelajaran. Metode pembelajaran yang dipilih akan berpengaruh terhadap hasil pembelajaran yang akan diraih. 59 Mengajar merupakan usaha guru menciptakan suasana belajar. Melalui metode pengajaran yang diterapkan guru diharap dapat membangun respon positif siswa pada kegiatan belajarmengajar.

Metode pembelajaran Role Playing atau sosio drama merupakan suatu metode penguasaan materi melalui penghayatan dan imajinasi siswa dengan cara memerankan suatu tokoh. Siswa dapat berekspresi sesuai dengan tokoh yang diperankannya. Siswa dapat menambah pengalaman belajarnya dalam hal kemampuan bekerja sama, menghayati perasaan orang lain, komunikatif, dan menginterpretasikan kejadian melalui peran. Siswa berusaha menggali interaksi antarmanusia melaui peragaan kemudian mendiskusikan dengan temannya sehingga output yang dihasilkan yaitu siswa mampu menggali sikap, nilai, perasaan, dan strategi memecahkan masalah. ${ }^{60}$

Metode role playing memiliki keunggulan pokok yaitu mampu melibatkan seluruh siswa dalam berpartisipasi dan menunjukkan kemampuannya didalam kelas, mampu berekspresi dan mengambil keputusan secara bebas, dan menciptakan pengalaan belajar menyenangkan. Sedangkan beberapa kekurangan yang harus diperhatikan dalam

59 Jumanta Hamdayama, "Metodologi Pengajaran", (Jakarta, PT. Bumi Aksara, 2016) hal 94

60 Ibid, hal 113 
Putri Aulia Enan Dina, Rasmuin : Implementasi Metode Belajar Role Playing untuk Meningkatkan Hasil Belajar Siswa Kelas VIII C Mata Pelajaran IPS Mtsn Batu

penerapan metode role playing yaitu waktu yang dibutuhkan sangat banyak, tempat yang disediakan harus luas, dan kerap terjadi kebisingan akibat suara pemain dan tepuk tangan penonton. Metode role playing mampu menarik minat dan perhatian siswa dalam belajar karena isu-isu sosial sangat menarik bagi mereka. Siswa memainkan peran sendiri sehingga ia lebih mudah memahami isu-isu sosial tersebut.

Penerapan metode role playing pada penelitian tindakan kelas ini dilalui berdasarkan beberapa siklus. Pada kegiatan pra siklus banyak dijumpai siswa belum mampu memenuhi Kriteria Ketuntasan Minimal (KKM) berdasarkan data nilai ulangan harian materi interkasi negara-negara ASEAN. Pengamat menyadari kurangnya antusias siswa dalam kegiatan belajar mengajar. Siswa dapat menempatkan diri seperti tokoh yang ia perankan, mampu merasakan perasaan orang lain, dan mengakui pendapat orang lain. Maka dari itu tumbuhlah sikap toleransi, saling mengerti, dan peduli terhadap sesama.

Kegiatan siklus I, peserta didik terlihat antusias mengikuti proses pembelajaran memakai metode role playing. Hal tersebut dapat menambah minat dan antusias belajar siswa sehingga berdampak positif pada perolehan hasil belajar. Berdasarkan data evaluasi siklus I, nilai siswa menunjukkan peningkatan rata-rata mencapai 76,2. Data menunjukan 12 dari 20 peserta didik sudah mampu memenuhi nilai KKM sebesar 75 sedangkan sisanya masih perlu adanya perbaikan. Berikut merupakan daftar nilai evaualasi siklus 1 . 
Putri Aulia Enan Dina, Rasmuin : Implementasi Metode Belajar Role Playing untuk Meningkatkan Hasil Belajar Siswa Kelas VIII C Mata Pelajaran IPS Mtsn Batu

Tabel 1: Daftar nilai evaluasi belajar siklus I

\begin{tabular}{|l|l|c|l|}
\hline No. & Inisial Siswa & Nilai & Keterangan \\
\hline 1. & AMI & 85 & Tuntas \\
\hline 2. & AT & 71 & Belum Tuntas \\
\hline 3. & AS & 85 & Tuntas \\
\hline 4. & AZR & 90 & Tuntas \\
\hline 5. & ANS & 88 & Tuntas \\
\hline 6. & CAN & 65 & Belum Tuntas \\
\hline 7. & DCN & 70 & Belum Tuntas \\
\hline 8. & FAP & 54 & Belum Tuntas \\
\hline 9. & HMA & 64 & Belum Tuntas \\
\hline 10. & ISA & 85 & Tuntas \\
\hline 11. & KWSA & 65 & Belum Tuntas \\
\hline 12. & MFFU & 75 & Tuntas \\
\hline 13. & MAP & 90 & Tuntas \\
\hline 14. & MPR & 75 & Tuntas \\
\hline 15. & MS & 82 & Tuntas \\
\hline 16. & MI & 70 & Belum Tuntas \\
\hline 17. & NNF & 90 & Tuntas \\
\hline 18. & VJPU & 60 & Belum Tuntas \\
\hline 19. & WFP & 85 & Tuntas \\
\hline 20 & ZMI & 75 & Tuntas \\
\hline NILAI RATA-RATA & 76.2 & \\
\hline Presentasi ketuntasan & $60 \%$ & \multicolumn{2}{|l}{} \\
\hline & & \multicolumn{2}{|l|}{} \\
\hline
\end{tabular}

Hasil pengamatan peneliti menggambarkan bahwa kondisi kelas ketika kegiatan belajar mengajar berlangsung sudah kondusif. Siswa aktif mendalami peran dan menganalisis dengan materi pembelajaran. Namun ditemukan beberapa siswa kurang memperhatikan instruksi guru dan tidak menghiraukan kegiatan pembelajaran. Selain itu masih ada beberapa kendala pada saat penggunaan metode pembelajaran role playing di dalam kelas, diantarnya kurangnya kerjasama dan koordinasi antar anggota kelompok sehingga saat pementasan drama banyak terjadi kesalahan peran, selain itu siswa kurang serius dalam kegiatan pembelajaran dan menganggap metode role playing hanya permainan semata. 
Putri Aulia Enan Dina, Rasmuin : Implementasi Metode Belajar Role Playing untuk Meningkatkan Hasil Belajar Siswa Kelas VIII C Mata Pelajaran IPS Mtsn Batu

Aktivitas selanjutnya yaitu pelaksanaan siklus II. Siklus II perlu diterapkan untuk membenahi hasil evaluasi dari siklus I. dilihat dari perolehan evaluasi (Post Tes) siklus II, hasil belajar siswa menampakkan adanya kenaikan dibandingkan dengan siklus I. Nilai rata-rata siswa sebesar 89,4 dan 18 dari 20 peserta didik sudah mampu memenuhi nilai KKM.

Hasil evaluasi yang dilakukan siswa cukup memuaskan, dapat kita amati pada daftar hasil evaluasi belajar siklus II dibawah ini.

Tabel 2: Daftar nilai evaluasi siswa pada siklus II

\begin{tabular}{|l|l|l|l|}
\hline No. & Inisial Siswa & Nilai & Keterangan \\
\hline 1. & AMI & 100 & Tuntas \\
\hline 2. & AT & 85 & Tuntas \\
\hline 3. & AS & 91 & Tuntas \\
\hline 4. & AZR & 92 & Tuntas \\
\hline 5. & ANS & 90 & Tuntas \\
\hline 6. & CAN & 90 & Tuntas \\
\hline 7. & DCN & 70 & Belum Tuntas \\
\hline 8. & FAP & 70 & Belum Tuntas \\
\hline 9. & HMA & 85 & Tuntas \\
\hline 10. & ISA & 100 & Tuntas \\
\hline 11. & KWSA & 100 & Tuntas \\
\hline 12. & MFFU & 93 & Tuntas \\
\hline 13. & MAP & 82 & Tuntas \\
\hline 14. & MPR & 82 & Tuntas \\
\hline 15. & MS & 85 & Tuntas \\
\hline 16. & MI & 94 & Tuntas \\
\hline 17. & NNF & 100 & Tuntas \\
\hline 18. & VJPU & 91 & Tuntas \\
\hline 19. & WFP & 100 & Tuntas \\
\hline 20 & ZMI & 88 & Tuntas \\
\hline NILAI RATA-RATA & & 89.4 \\
\hline Presentasi ketuntasan & & $90 \%$ \\
\hline
\end{tabular}

Berdasarkan data pengamatan, hasil belajar siswa kelas VIII-C mengalami perubahan positif dilihat dari nilai evaluasi siklus II. Grafik dibawah ini menggambarkan hasil belajar 
Putri Aulia Enan Dina, Rasmuin : Implementasi Metode Belajar Role Playing untuk Meningkatkan Hasil Belajar Siswa Kelas VIII C Mata Pelajaran IPS Mtsn Batu

peserta didik ditinjau dari perbedaan nilai evaluasi pada aktivitas Pratindakan, Siklus I, dan Siklus II kelas VIII-C MTs Negeri Batu:

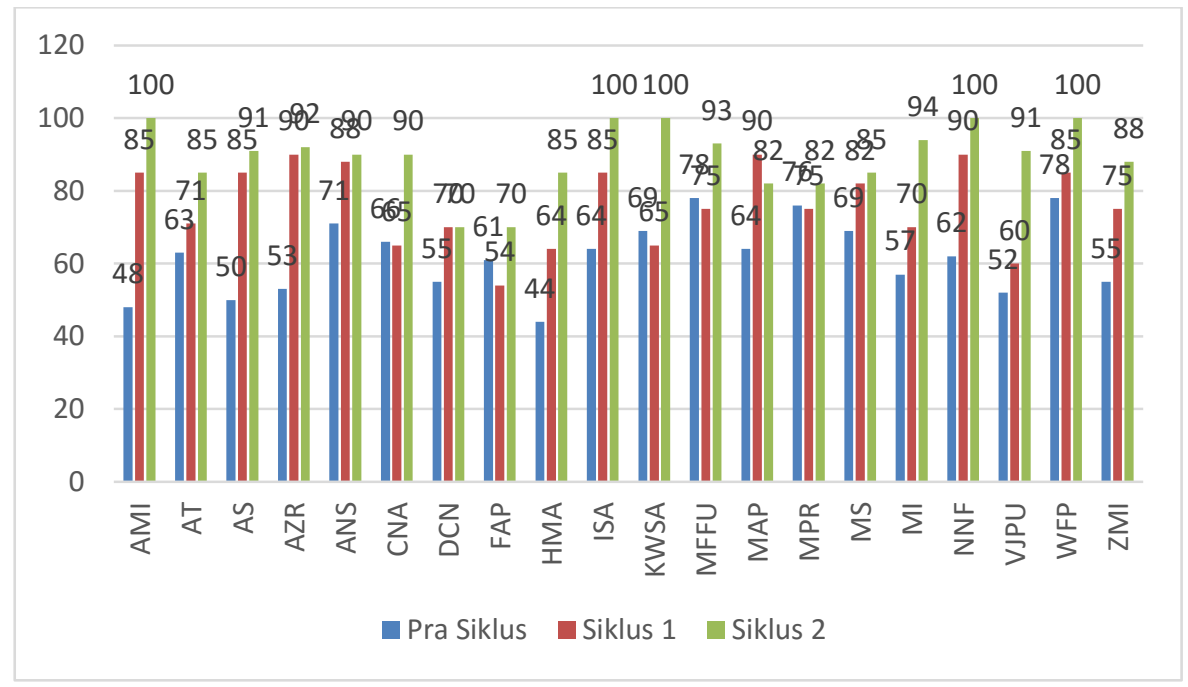

Gambar 1. Grafik nilai evaluasi pra tindakan, siklus I, dan

\section{Siklus II}

Penggunaan metode ini yang dilakukan berulang dalam dua siklus menimbulkan masalah baru. Bersadarkan wawancara dengan salah satu peserta didik mereka merasa bahwa penggunaan metode role playing yang diulang-ulang terasa membosankan. Selain itu waktu yang diberikan untuk persiapan sangat singkat. Hal ini perlu adanya kreatifitas guru dalam menyiapkan dan melakukan pembelajaran dengan menggunakan metode Role Playing agar tidak cenderung membosankan walau dilaksanakan pada beberapa pertemuan. Manajemen waktu dalam kegiatan pembelajaran juga perlu diperhatikan sehingga kegiatan pembelajaran dapat terlaksana secara menyeluruh. 
Putri Aulia Enan Dina, Rasmuin : Implementasi Metode Belajar Role Playing untuk Meningkatkan Hasil Belajar Siswa Kelas VIII C Mata Pelajaran IPS Mtsn Batu

\section{KESIMPULAN}

Berdasarkan penelitian pada kelas VIII-C MTs Negeri Batu dap1at disimpulkan bahwasannya implementasi metode belajar Role1 Playing pada materi1 mobilitas sosial mampu meningkatkan antusias belajar siswa. Hal ini dapat mempengaruhi peningkatan kognitif siswa sehingga mampu berdampak positif terhadap hasil belajar siswa. Ditinjau dari hasil evaluasi (Post tes) memperlihatkan bahwa niali rata-rata pra siklus hingga kegiatan siklus II membuktikan adanya peningkatan yang signifikan. Rata-rata nilai evaluasi pra siklus yang diperoleh dari data Ulangan1 Harian sebesar 61,75, hasil evaluasi siklus I mengindikasikan1 rata-rata nilai sebesa1r 76,2 sedangkan rata1-rata nilai pada siklus1 II naik menjad1i 89,4. Namun perlu adanya variasi lebih lanjut dalam melaksanakan metode Role Playing agar peserta didik tidak bosan jika dilakukan berulang-ulang kali pada pertemuan selanjutnya. 
Putri Aulia Enan Dina, Rasmuin : Implementasi Metode Belajar Role Playing untuk Meningkatkan Hasil Belajar Siswa Kelas VIII C Mata Pelajaran IPS Mtsn Batu

\section{DAFTAR PUSTAKA}

Baroroh, Kiromim. 2011. Upaya Meningkatkan 1Nilai-Nilai Karakter Peserta Didik Melalui Penerapan 1Metode Role Playing. Jurnal Ekonomi \& Pendidikan. Volume 8 Nomor 2

Djamarah, Syaiful Bahri dan Aswan Zain. 2002. Strategi Belajar Mengajar. Jakarta: Rineka Cipta

Djamarah, Syaiful Bahrir. 2005. Psikologi1 Belajar. Jakarta: PT. Rineka Cipta

Hamdayama, Jumanta. 2016. Metodologi Pengajaran. Jakarta: PT. Bumi Aksara

Kartini, Tien. 2007. "Penggunaan Metode Role Playing untuk meningkatkan minat siswa dalam pembelajaran pengetahuan sosial di kelas V SDN Cileunyi I Kecamatan Cileunyi Bandung”. Pendidikan Dasar, Nomor: 8

Mardiyan, Riry. 2012. "Peningkata Keaktifan dan Hasil Belajar Siswa dalam Pembelajaran Akuntansi Materi Jurnal Penyesuaian pada Siswa Kelas XI IPS 3 SMA Negeri 3 Bukit Tinggi dengan Metode Bermain Peran(Role Playing)". Pakar Pendidikan, VOL. 10 NO. 2

Murtadlo, Muhamad Nukha. 2012. "Penerapan Metode Role Playing pada Standar Kompetensi Memahami Kegiatan pelaku Ekonomi di Masyarakat Mata Pelajaran IPS Ekonomi Sebagai Upaya Peningkatan Hasil Belajar SMP 4 Kudus". Economic Educatin Analysis Journal 1 (1)

Permana, Septian Aji. 2017. Strategi Pembelajaran IPS Kontemporer. Yogyakarta: Media Akademi

Slameto. 2010. Belajar dan Faktor yang mempengaruhinya. Jakarta: Rineka Cipta

Uno, Hamzah B. 2008. Model Pembelajaran. Jakarta: Bumi Aksara

Yamin, Moh. 2014. Teori dan Metode Pembelajaran. Malang: Madani 